\title{
The effect of the leadership towards employee performance in the human resources department at the PLN west java and banten distribution office
}

\author{
Arif Partono Prasetio $^{1 *}$, Syahrizal Siregar ${ }^{1}$, Bachruddin Saleh Luturlean ${ }^{2}$ \\ ${ }^{1}$ Telkom University Schools of Business and Economic \\ ${ }^{2}$ Telkom University School of Business and Communication \\ *Corresponding author E-mail: partono67@gmail.com
}

Copyright () 2015 Arif Partono Prasetio et al. This is an open access article distributed under the Creative Commons Attribution License, which permits unrestricted use, distribution, and reproduction in any medium, provided the original work is properly cited.

\begin{abstract}
Every organization needs to focus on the employee performance if they want to thrive in the business. There are many factors which affect the employee performances. Leadership believes to be the crucial factors which can affect the employee performance. The organization will ensure they develop good leaders to support the employee to get results. This research will analyze the relation between the leadership and employee performance at the PLN West Java and Banten Office. We used 27 respondents which represent total employee in the Human Resources Department. The selection of the respondents based on the fact we had close relation with all the employees at the human resources department. This relation will add our analysis with the depth interactive interview. We use simple regression and descriptive analysis to analyze the effect of the leadership towards the performance. We hope the research will benefit the field of human resources especially in the discussion about leadership and performance. The research underlining the importance of the leader's role in order to drive the employee performance. If leader can show the attitude and behavior which accordance to the employee needs, then the good relations will emerge and it will influence the performance.
\end{abstract}

Keywords: Human Resources Functions; Leadership; Motivation; Performance; Path-Goal Theory.

\section{Introduction}

The relationships between leadership and performance have been discussed many times in various researches. The measurement of the relationships also had been done using a variety of indicators or dimensions. This study will examine the influence of leadership on employee performance in the Human Resources Department of PLN Distribution Office in West Java and Banten. The important thing which attracts the author to conduct the research was the employee performance measurement system applied at PT. PLN. They have used the method of performance measurement that is associated with an employee promotion process. There were nine Talent Criteria; LBS (Extra Ordinary), SOP (Highly Optimized), SPO (Very Potential), OPT (Optimized), POT (Potential), KPO (Potential Candidate), PPS (Need Adjustment), PPE (Need Attention), and SPP (Desperately need attention). The ninth talent criteria obtained from a combination of Performance Measurement and Individual Competence Evaluation. The combination has four stages.

The first stage was when the company performs the Measurement of The Employee Contract Achievement Performance Goals which represents a compilation of Measurements Targeting Employee Performance and Employee SelfDevelopment Program (PDP Program). 
Table 1: Measurement of Performance

\begin{tabular}{lll}
\hline Performance Score & The Measurement of Performance Target & Abbrv. \\
\hline $401-500$ & Pencapaian Luar Biasa (Outstanding) & OS \\
$301-400$ & Melampaui Harapan (Exceeds Requirements) & ER \\
$201-300$ & Memenuhi Persyaratan (Meet Requirements) & MR \\
$101-200$ & Perlu Pengembangan (Need Improvement) & NI \\
$0-100$ & Pencapaian Minimum (Marginal) & MG \\
\hline$*$ We used Bahasa in order not to make mistake in understanding the terms used &
\end{tabular}

The second stage was the Individual Competence Measurement which performs with the consideration of the various sources and involving their supervisor. The result will describe the percentage level of their achievement in Individual Competency (KI) compare to the Job Competence Requirement (KKJ).

Table 2: Measurement and Evaluation of Individual Competence

\begin{tabular}{lll}
\hline Individual Competence Score & Result of Individual Competence Measurement & Abbrv. \\
\hline $401-500$ & Kompetensi Sangat Istimewa (very special) & KOM-1 \\
$301-400$ & Kompetensi Istimewa (special) & KOM-2 \\
$201-300$ & Kompetensi Rata-rata (average) & KOM-3 \\
$0-200$ & Kompetensi Kurang Ditampilkan (below average) & KOM-4 \\
\hline$*$ We used Bahasa in order not to make mistake in understanding the terms used
\end{tabular}

Next, the third stage was the definition of the Talent Criteria which is the combination from the results of Measurement of the Employee's Contract Achievement Performance Goals and Individual Competency measurement. The following tables describe the combination.

Table 3: Talent Criteria Measurement

\begin{tabular}{|c|c|c|c|c|c|}
\hline \multirow{2}{*}{ The Result of Individual Competence Measurement } & \multicolumn{5}{|c|}{ The result of Target Performance Measurement } \\
\hline & MG & NI & MR & ER & OS \\
\hline KOM-1 & & & & SPO & LBS \\
\hline KOM-2 & & KPO & POT & OPT & SOP \\
\hline KOM-3 & PPE & KPU & PU1 & UP1 & \\
\hline KOM-4 & SPE & PPS & & & \\
\hline
\end{tabular}

The last stage was the part when the company provides an assessment of each employee. This research uses only respondents who worked in the Department of Human Resources only, so the following section will present the results of an assessment of 12 employees. The author cannot get the data for all employees in this section because of the confidentiality reason. According to the Human Resources manager, the data provided to us represent the results of the assessment in the Department of Human Resources as a whole. Here are the results of assessment for two semesters in 2013 for the twelve employees.

Table 4: Human Resources Staff Performance Pt. Pln Distribution Office West Java and Banten $1^{\text {st }}$ and $2^{\text {nd }}$ Semester 2013

\begin{tabular}{llll} 
& Table 4: Human Resources Staff Performance Pt. Pln Distribution Office West Java and Banten $1^{\text {st }}$ and $2^{\text {nd }}$ Semester 2013 \\
\hline No & Employee & Talent Criteria & Second Semester \\
\hline 1 & First Semester & OPT \\
2 & STAFF 1 2 & OPT & OPT \\
3 & STAFF 3 & OPT & OPT \\
4 & STAFF 4 & OPT & POT \\
5 & STAFF 5 & POT & POT \\
6 & STAFF 6 & OPT & OPT \\
7 & STAFF 7 & OPT \\
8 & STAFF 8 & POT & OPT \\
9 & STAFF 9 & SPO & POT \\
10 & STAFF 10 & OPT & POT \\
11 & STAFF 1 & OPT & POT \\
12 & STAFF 12 & POT & POT \\
\hline
\end{tabular}

Based on the previous data, there were there were 4 people who experience the decline in their performance assessment and there was only one person who experienced an increase in performance. This is the background why the study was conducted. In the midst of a positive view about the leaders in the HR Department, the employee performance was not reflects the company's expectations. The HR Manager already built the good relationships with employees. But still, there were employees who are late for work or missing from work during working hours. Whereas with the leadership style that is warm, that was not supposed to happen. On the contrary, it might happen because of the leniency of the 
regulatory for employees. The author would like to know whether the leadership variable affect the employee performance or there are other factors at play. A good leader should keep the balanced between managing the team work and achieving their targets. Therefore if the below standard performance was caused by the leadership, then there should be a corrective action applied in the organization.

The leadership is defined by Amstrong [1] as the process in inspiring the employee to do the job and achieve the individual and organization goals. Leadership is when someone inspired the other so they are willingly performs maximum effort to achieve the target. The leader's role is obvious to motivate or drive the employee to do their best. If we talk about the leaders then we should consider their characteristics and their style. There are many leadership approaches ranging from trait and personalities, behavioral, contingency or situational, transactional, transformational, and self-leadership approach [2]. This research will use the leadership style from House [3], the Path-Goal Theory of leadership effectiveness. The path-goal theory which categorized under contingency leadership approach concentrates on the interaction between the variables involved in a leadership situation and patterns of leadership behavior. It is based on the thought that an employee's motivation depends on the expectations that putting more effort can lead to better performance. House [3] argues that the various leadership behaviors can be practiced in different circumstances and times by the same leader. With the adjustment of their style, managers try to affect their subordinates, and pave the way for achieving their shared goals.

Path-Goal theory has four pillar; Directive Leadership (inform or tell the followers what to do and how to achieve it), Supportive Leadership (concern about the subordinate's welfare and needs), Achievement Leadership (set challenging goal and increase the self-confidence of the subordinate), and Participative Leadership (involve team members in making decision and problem solving). The theory stressed the idea of the attitude and behavior of the leader which can drive the motivation, satisfaction, and performance of the subordinate. If the leader has a positive attitude and can apply helpful motivating techniques, then the employee will achieve higher performance levels [4].

For the second variable, the performance, the author used the concept of Prawirosentono [5]. Performance defined as the result of work achieved by a person or group of people in an organization. Performance is the result of work within a specific time period that indicates a person's level of achievement in meeting organizational goals. Individual's performance can be measured based on the dimensions or performance indicators. Miner [1] suggests four dimensions of performance; the quality, the quantity, effectiveness of time, and the relations with others. We used this four indicators to measure the level of performance perceive by the employee of HR Department at PLN Distribution Office for West Java and Banten. These four indicators reflect the performance system applied in the organization which already explained.

As the author explained, there are many research discuss the relation between leadership and the performance. They use various variables to measure the relations. Astuti [6] used the Situational Leadership Style from Hersey and Blanchard. She found that there is a significant and positive relationship between leadership and the employee performance. The other researcher, Lusiani [7] said that there is also significance and positive relations between Headmaster leadership style and the teacher performance. She used the transformational leadership as variable. The result from the Indonesian organization was backed by the international findings. Pradheep \& Prabhu (2011) showed that through the correlation and regression analysis they found that the transformational leadership style has significant relationships with performance. Furthermore, Abbas \& Yaqoob [8], which conducted the study using five factors of leadership development (coaching, training and development, empowerment, participation and delegation), found that the combined effect influenced employee performance. They said that as the five variables of leadership collectively prove as a synergic effect and increase the overall employee performance. The Iranian researchers, Shafie et al [9] using the development-oriented and pragmatic-oriented leadership style as variable also found that leadership had a positive impact on employee performance. The last scientific research was come from Pakistani researchers, Paracha et al [10]. They said that the transactional and transformational both are significantly positive associated with employee performance. It noted special case that transactional leadership was more significant than the transformational style. Finally the research from Rebecca and Jonathan [4] found that by applying several styles from the path-goal theory, Columbia Records executives and chairmen have made the organization become the most successful in history.

This research will analyze the leadership style based on the path-goal theory and the employee performance. Therefore, the hypothesis for the research:

H0: The leadership style has no significance effect towards the employee performance

H1: The leadership style has significance effect towards the employee performance

\section{Methodology}

The research used all the employees in Human Resources Department at PLN Jawa Barat and Banten Office which has he total employee is 27 . The small number might not quite sufficient for the quantitative research. But this is the population so we were sure that the result is reflecting the real condition. The $44 \%$ of the employee already served more than ten years of service, so they can give the detail information about the company. The items in the questionnaire were design based on the variables used. We used 20 questions to measure the leadership style and 10 questions for the employee performance. 
The writer use statistical analyses to test the hypothesized relationships for both variables. We use the simple linear regression methods using SPSS 22. Before using the data to measure the linear regression we also analyze the validity and the reliability of the data. The $t$ calculated for all the indicators in variables $\mathrm{X}$ and $\mathrm{Y}$ are bigger than the $\mathrm{t}$ table. So, all the items in the questionnaire met the validity test. We use Cronbach's alpha method to test the reliability and the result shown that all indicators are bigger than 0.70 [11], hence they all reliable.

We are using the descriptive method to explain the leadership style and employee performance. Of course, we used the questionnaire to get the answer from the respondents. We measure the level of service quality and loyalty using modified Likert Scale. We did not use the mid-point to avoid the social desirability bias, arising from respondents' desires to please the interviewer or appear helpful or not be seen to give what they perceive to be a socially unacceptable answer [12].

Using Excel application, we sum all the answer for leadership questions. We also calculate the result representing the four style directive, supportive, achievement, and participative. We have 4 scales for each dimension; scale 1 representing very weak perceptions, scale 2 classified as weak perceptions, scale 3 for strong, and scale 4 for very strong perceptions. We get the total result, and calculate the average for each style. The next step is to multiply each answer in each dimension with the scale. For example the average for tangible dimension in scale 2 is 4.4 . We multiply the 4.4 with 2 and we do this for the rest of the directive style (scale 3 and 4). The total result for directive style is 78 (72.2\% from total of 108). It means the employee perceive that the leader applying the directive style. The result for the rest of the style calculated and the result show the average of 77.65 or $71.9 \%$, which means the leader applying strong leadership style. For the employee performance variable, we conduct the same calculation method.

To measure the level of leadership style and performance, we used the continuum line. The steps to draw the continuum line setting the lowest level of the figure. For this research of course it is 27 . If we assume all samples choose the scale 1 for all questions, then we get 27. The highest point is 108 (all respondent give the scale 4). We draw the straight line and divided it by the number of scale used (four). To set the distance range we subtracted 108 (highest) with 27 (lowest) then divide the result by four. The final step is to put the figure from leadership style and performance on the line. This way, we know how's the strength of the leadership style and the employee performance (as perceived by the employee). As usual, to measure one independent variable effect on the dependent variable we use the simple linear regression [11]. There are at least two tests to evaluate whether the data can be used for simple linear regression. The normality test used to measure whether the data normally distributed or not and in this case, One Sample Kolmogorov Smirnov method used to perform the normality test. The other test will evaluate whether any heterocedasticity or not. The Glejser Test used to test them. The final step is using Anova table. The standard figure for Sig. is below 0.05 and based on the test we know that the data normally distributed, there are no heterocedasticity, and there is linear relation for both variables [11].

\section{Result}

PLN, the Distribution Office for West Java and Banten responsible for the electricity supply for the area covered. The mission carried by this state-owned company is to become the world class company which grew, develop, competitive, and trusted based on their HR potential. The organization should provide the electricity for the whole West Java and Banten covering the area of $42.196 \mathrm{~km}^{2}$. Their customer now is reach more than 9 million, which equal the $22 \%$ of the national customer for PLN Indonesia. Carrying this difficult task PLN required to their human resources performance. Despite the bad image of the state-owned company, PLN already made some improvement to gain the customer's trust. One of the break-through was that they will not allow their employee to take the gratitude from the customer. Even, they have a dedicated line to report such incident if it happened. The other policy which showed the good intention of PLN is the transparency in their process. Much of the customer service documented and served in an open system. They also try to make the payment regarding their services transparent through the use of online or offline payment which administered by other parties (PT. POS, banking). The path to the improvement will only succeed if the employees support the system. In order to drive and motivate the employee PLN should prepare their leader to become aware to the employee's need. It is not to fulfill all of their need of course. But by doing this, leader can easily identify the best way or approach to drive their subordinate. Understanding the employee means that leader should practice different approach for different employee at the different situation. By carefully applying various leadership behaviors, the managers hopefully can affect their subordinates, and cruising to achieve their goals.

As the table 2 showed us, the path-goal leadership style in HR Department, PLN West Java \& Banten seems applied well enough. According to the figure shown, all of the pillars score are above $70 \%$ which belong to strong category in the continuum line (see Figure 1). The perceptions average show that 77.65 or $71.9 \%$ of the employee agree their leader practicing the various style of the path-goal theory. This mean the head of HR Department exercised different style of leadership for different situations. This is important since the leader objectives is to provide guidance, support, and help for their subordinates in achieving their goals and the organization goals. Besides, leader should be able to identify the subordinate's task and needs and then practice the related style. It also seems that this leader possess special requirement to know which style that suitable for the specific occasion. When the subordinate need help and attention then leader should practice the supportive role. This kind of situation will build employee motivation and satisfaction 
which can lead to the great performance. After all, we are human beings whose needs are continually changing. So the best way to cope is to continuously adjust.

Table 5: The Leadership Style

\begin{tabular}{lllllll}
\hline & 1 & 2 & 3 & 4 & 27 & 108 \\
& VW & W & S & VS & & \\
\hline Directive & - & 4.40 & 21.20 & 1.40 & 78.00 & $72.2 \%$ \\
Supportive & - & 4.43 & 21.29 & 1.29 & 77.86 & $72.1 \%$ \\
Achievement & - & 6.75 & 18.50 & 1.75 & 76.00 & $70.4 \%$ \\
Participative & 0.25 & 3.75 & 21.00 & 2.00 & 78.75 & $72.9 \%$ \\
& & & & & 77.65 & $71.9 \%$ \\
\hline
\end{tabular}

VW= Very Weak; W= Weak; S= Strong; VS= Very Strong

\begin{tabular}{|c|c|c|c|}
\hline 27 & 47.25 & 67.5 & 87.75 \\
\hline VERY WEAK & WEAK & STRONG & VERY STRONG \\
\hline
\end{tabular}

Fig. 1: Continuum Line for Leadership Style

The $71.9 \%$ indicating that employee believe their leader can adapt to their needs. The organization should maintain this condition and even they should increase the perception. The higher the perception will mean that the employee will feel better regarding the leadership style of their manager. Now, there is still minor disagreement between manager and staff. With the passage of time, and they know more about each other, they bondage will be stronger.

As the previous research found, the practice of the path-goal leadership style will increase the employee performance. So if the organization needs to be succeeded in their business, they have to increase the performance of their human resources. From the Table 2, we can say that the performance level of the employee is quite good. We use four performance dimensions.

\begin{tabular}{|c|c|c|c|c|c|c|}
\hline & $\begin{array}{l}1 \\
\text { VLL }\end{array}$ & $\begin{array}{l}2 \\
\mathrm{~L}\end{array}$ & $\begin{array}{l}3 \\
\mathrm{H}\end{array}$ & $\begin{array}{l}4 \\
\mathrm{VH}\end{array}$ & 27 & 108 \\
\hline Quantity & 0 & 2 & 21.5 & 3.5 & 82.50 & $76.4 \%$ \\
\hline Quality & 0 & 1.5 & 22.5 & 3 & 82.50 & $76.4 \%$ \\
\hline Attendance & 0 & 4.25 & 20 & 2.75 & 79.50 & $73.6 \%$ \\
\hline Relations & 0 & 0.5 & 23.5 & 3 & 83.50 & $77.3 \%$ \\
\hline
\end{tabular}

VW= Very Weak; W= Weak; $S=$ Strong; VS= Very Strong.

All four dimensions show the average point of $75.9 \%$. This mean the employee perceive their performance is rather high. Compare to the performance appraisal conducted by the organization, this percentage seems quite match. Even though already at the high level, they are still below the $80 \%$. There are rooms for improvement. With the extra effort to manage the leadership style, this could happen in the near future.

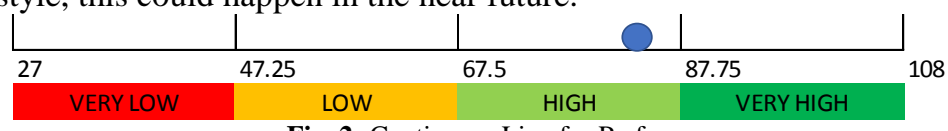

Fig. 2: Continuum Line for Performance

The result showed that the practice of path-goal leadership style and employee performance indicated that the organization already perform well. The leadership style has significance positive relation with the employee performance. If the employee perceived that their leader applied the path-goal leadership then their performance will increased.

We use the simple linear regression to measure to influence of service quality and the loyalty. Before conducting the regression we must measure the normality of the data. Using One Sample Kolmogorov Smirnov, we get the Asymp. Sig. (2-tailed) of 0.200 which is bigger than 0.05 , so research data normally distributed. Next we conduct the Glejser Test to find whether there is heterocedasticity or not. The result show the sig. for the leadership style is 0.325 and it is bigger than 0.05 . So there are no heterokedasticity problems. To make sure whether data linear or not, we analyze the ANOVA table below.

Table 7: Anova $^{\mathrm{a}}$

\begin{tabular}{|c|c|c|c|c|c|c|}
\hline \multicolumn{2}{|c|}{ Model } & Sum of Squares & $\mathrm{df}$ & Mean Square & $\mathrm{F}$ & Sig. \\
\hline \multirow{3}{*}{1} & Regression & 174.730 & 1 & 174.730 & 43.103 & $.000^{\mathrm{b}}$ \\
\hline & Residual & 101.344 & 25 & 4.054 & & \\
\hline & Total & 276.074 & 26 & & & \\
\hline
\end{tabular}

a) Dependent Variable: Performance

b) Predictors: (Constant), Leadership 
The sig. result 0.0000 indicating that the leadership style and employee performance has linear relations and the leadership style significantly influenced the performance. We can continue to perform the simple linear regression analysis. Let's take a look at the Coefficients table below and discuss the results.

Table 8: Coefficients ${ }^{\mathrm{a}}$

\begin{tabular}{|c|c|c|c|c|c|}
\hline \multicolumn{6}{|c|}{ 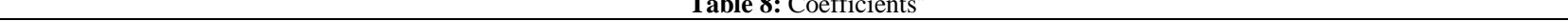 } \\
\hline \multirow{2}{*}{ Model } & \multicolumn{2}{|c|}{ Unstandardized Coefficients } & \multirow{2}{*}{$\begin{array}{l}\text { Standardized Coefficients } \\
\text { Beta }\end{array}$} & \multirow[b]{2}{*}{$\mathrm{t}$} & \multirow{2}{*}{ Sig. } \\
\hline & $\mathrm{B}$ & Std. Error & & & \\
\hline (Constant) & 7.698 & 3.447 & & 2.233 & .035 \\
\hline Leadership & .391 & .060 & .796 & 6.565 & .000 \\
\hline
\end{tabular}

The simple linear regression equation is $\mathrm{Y}=7.698+0.391 \mathrm{X}$. The equation reveals that if the path-goal leadership style is not practice, then the performance is 7.698 units. When the employees perceive the manager apply the path-goal leadership style then the performance will increase as of 0.391 . In the social sciences it will be difficult to put number to describe the level of leadership style and performance. So in this case it is safe just to describe that both variables has linear and significant relations.

Table 9: Model Summaryb

\begin{tabular}{lllll}
\hline Model & R & R Square & Adjusted R Square & Std. Error of the Estimate \\
\hline 1 & $.796^{\text {a }}$ & .633 & .618 & 2.01339 \\
\hline a) & Predictors: (Constant), Leadership & & \\
b) & Dependent Variable: Performance & &
\end{tabular}

The R figures 0.796 show that there is strong relation between leadership style and the employee performance. The variation in applying path-goal leadership style will affect the performance in the amount of $63.3 \%$. So $63.3 \%$ of the performance can be explained by the leadership style, whereas the rest of it (36.7\%) explained by other factors not discussed in this research.

As to decide which of the two hypotheses will be accepted, we perform the t test. The t calculate figure show 6.565 , whereas the t table $(0.1,86-2)$ is 2.06 , which mean that the $\mathrm{H} 0$ is rejected and $\mathrm{H} 1$ accepted. To confirm this finding we look at the sig. figure which is 0.000 (lower than 0.005 ). So, based on the significance from the figure 5 we accept the H1. This research confirms the previous one about the positive influence of the leadership style towards the employee performance. And for the standard of error figure 2.013, it means we have the possibility of error $2.01 \%$ regarding of this result analysis.

\section{Discussion}

Based on thee result above, we found that the leadership has influence towards the performance. Thus, the PLN should focus on building the leadership style which match the employee need. The path-goal style which emphasize on the leader's involvement into the employee's work show the positive result. It mean that the employee feel secure and happy to see their supervisor around them. This might be because the present of the supervisor give security and satisfction that their work will be rewarded fairly. But, the strong binding between leader and performance should not overlook because there are other factors that influence the performance. PLN then must analyze which factors that also contribute to the performance. They need to look over the training and development practice, the motivation factors, the scheme of challenging works, and also the company's policy. With a lot of factors been consider and practiced, PLN can assure the high performance level among their employee can be maintained.

\section{Conclusion}

We conclude the result by saying that the leadership style is one of the important factors if the organization wants to drive and motivate their employee. The leadership style can affect the motivation and of course the performance of the employee. As we seen from this research and others, the leader factor is crucial. Please note that we deal with the human being. They are have dynamic and ever changing needs. So the organization should provide them with the leaders who can accommodate the need of the employee and adjusting them to the organization needs or goals. If both needs going in the same way, then employee and organization will experience great benefit. Even though often look as the old way of leadership approach, the Path-goal theory which explained that the behavior of the leaders which affect the subordinate' satisfaction, motivation and performance still become one of the best approaches. The leader should practice different behavior, in different situations, times, and for each subordinate. The empirical researches to test the path-goal theory should conduct in various industries. At least to measure whether the proposition of the leader behavior that affect the motivation, satisfaction, and performance still recognized. The author also noted that the research regarding the Path-goal theory is still limited so it is important for the subsequent research to study the relation 
of this approach with other variables, such as commitment, loyalty, and intention to leave. In this way, we can expand the study of the Path-goal theory and enrich the viewpoint from different perspectives.

\section{References}

[1] Sudarmanto. (2009) Kinerja dan Pengembangan Kompetensi SDM. Yogyakarta: Pustaka Pelajar.

[2] Alanazi, T.R., \& Rasli, A.M. (2013). Overview of Path-Goal Leadership Theory. Comprehensive Research Journal of Management and Business Studies Vol. 1, No. 1, pp. 001-006.

[3] House, R.J. (1971). A Path Goal Theory of Leader Effectiveness, Administrative Science Quarterly, Vol. 16, No. 3, pp. 321-339. http://dx.doi.org/10.2307/2391905.

[4] Rebecca, V. \& Jonathan, M. (2011) Path-Goal Theory: A Successful Columbia Records Story, Journal of Human Behavior in the Social Environment, Vol. 21 No. 4, pp 350-362. http://dx.doi.org/10.1080/10911359.2011.555651.

[5] Subekhi, A. \& Jauhar, M. (2012) Pengantar Manajemen Sumber Daya Manusia (MSDM). Jakarta: Prestasi Pustaka.

[6] Astuti, S. (2013). Pengaruh Gaya Kepemimpinan Terhadap Kinerja Pegawai (Studi Tentang Gaya Kepemimpinan Situasional) Pada Kantor Pelayanan Pajak Pratama Medan Petisah. Thesis. Universitas Sumatra Utara, Medan. http://repository.usu.ac.id/handle/123456789/38168. Accessed 30 October 2014.

[7] Lusiani, D. (2012). Analisis Pengaruh Gaya Kepemimpinan Terhadap Kinerja Pegawai (Studi Kasus Sekolah Madania Parung-Bogor). Skripsi. IPB, Bogor. http://repository.ipb.ac.id/handle/123456789/57091. Accessed 30 October 2014.

[8] Abbas, Q. \& Yaqoob, S. (2009). Effect of Leadership Development on Employee Performance in Pakistan. Pakistan Economic and Social Review Vol. 47, No. 2, pp. 269-292.

[9] Shafie, B., Baghersalimi, S., \& Barghi, V. (2013). The Relationship between Leadership Style and Employee Performance (Case Study of Real Estate Registration Organization of Tehran Province). Singaporean Journal of Business Economics and Management Studies. Vol. 2, No. 5, pp. 21-29. http://dx.doi.org/10.12816/0003885.

[10] Paracha, M.U., Qamar, A., Mirza, A., Inam-ul-Hassan, Waqas, H. (2012). Impact of Leadership Style (Transformational \& Transactional Leadership) On Employee Performance \& Mediating Role of Job Satisfaction, Study of Private School (Educator) In Pakistan. Global Journal of Management and Business Research. Vol. 12, Issue 4.

[11] Priyatno, D. (2012). Cara Kilat Belajar Analisis Data dengan SPSS 20. Yogyakarta: Andi Offset.

[12] Garland, R., 1991. The Mid-Point on a Rating Scale: Is it Desirable? Marketing Bulletin Vol. 2, pp. 66-70. 